\title{
Baltic Labour in the Crucible of Capitalist Exploitation: Reassessing 'Post-Communist' Transformation
}

\section{Andreas Bieler}

University of Nottingham, United Kingdom of Great Britain and Northern Ireland

\section{Jokubas Salyga}

University of Nottingham, United Kingdom of Great Britain and Northern Ireland

Corresponding author: Jokubas Salyga, University of Nottingham - School of Politics and IR, University Park, Nottingham NG7 2RD, United Kingdom. Email:

Jokubas.Salyga@nottingham.ac.uk

(for copyright, not for publication A Bieler email: Andreas.Bieler@nottingham.ac.uk)

\section{Abstract}

Thirty years after the fall of the Berlin Wall, this article re-assesses 'post-communist' transformation in the Baltic countries from the perspective of labour. The argument is based on a historical materialist approach focusing on the social relations of production as a starting point. It is contended that the uneven and combined unfolding of 'post-communist' transformation has subjected Baltic labour to doubly constituted exploitation processes. First, workers in Estonia, Latvia and Lithuania have suffered from extreme neo-liberal restructuring of economic and employment relations at home. Second, migrant workers from Central and Eastern Europe in general, trying to escape exploitation at home, have faced another set of exploitative dynamics in host countries in Western Europe such as the UK. Nevertheless, workers have continued to challenge exploitation in Central and Eastern Europe and also in Western Europe, and have been active in extending networks of transnational solidarity across the continent. 


\section{JEL Codes: E11, E24, J61}

\section{Keywords}

post-communist, transformation, labour, migration, exploitation, capitalist expansion, historical materialism, Central and Eastern Europe, Baltic states, class struggle

\section{Introduction}

It was thirty years ago that the Berlin Wall came down and the political separation between Eastern and Western Europe came to an end. Liberal triumphalists heralded the falling apart of the so-called 'Eastern Bloc' as a success of representative democracy and the free market, facilitating Central and Eastern European (CEE) countries' 'historical return' to Europe as part of the end of history (Fukuyama, 1989). Dissatisfaction over economic recessions during the early 1990s was pacified through the promises of economic well-being as a result of the European Union (EU) membership. This process started in earnest with the formulation of the Copenhagen criteria at the European Council in Copenhagen in 1993 and eventually resulted in accession to the EU by the Czech Republic, Slovakia, Hungary, Poland, Slovenia, Latvia, Lithuania and Estonia in 2004, followed by Bulgaria and Romania in 2007 and Croatia in 2013.

This article re-assesses 'post-communist' transformation from the perspective of labour, with a specific focus on the Baltic countries Estonia, Latvia, and Lithuania. In particular, it asks to what extent workers have actually benefited from transformation to 'free market capitalism'. In the next section, mainstream approaches to 'post-communist' transformation, including orthodox transformation accounts plus institutionalist alternatives, are critically assessed, and the necessity of a historical materialist approach is asserted. Next, the structuring conditions of capitalism and their effect on the European political economy in general are discussed, including the implications of neo-liberal restructuring for trade unions. The third section analyses the dual way through which Baltic labour is exploited, both via the radical 
deregulation and liberalisation of their economies including labour markets and also via the way CEE workers are being exploited as migrants within Western Europe. Nevertheless, capitalism is never unchallenged. The fourth section highlights how labour has continued to resist exploitation against all odds. Finally, it is concluded that although conditions of transformation were not bereft of monumental political gains (ideological defeat of Stalinism, rights of freedom of speech, assembly, organisation and to vote), Baltic workers have found themselves in vulnerable positions of exploitation within uneven and combined development across the European political economy.

\section{Uneven and combined development across the EU}

The orthodox transformation paradigm in the early 1990s revolved around an advocacy of highly stylised, one-size-fits-all blueprints promoting the depoliticisation of ownership and allocation mechanisms, marketisation of the economy and subjection of enterprises to a hard budgetary constraint. While 'transition' schemes, drafted in the offices of international institutions and think tanks as well as economics departments, exhibited blindness towards 'distorting' influences of histories, societal configurations and politics in the 'target states' (Lipton and Sachs, 1990), subsequent institutionalist interventions questioned Washington Consensus policy mantras (Amsden, et al., 1994). It was recognised that the diversity of 'transition' paths and destinations rested on multifaceted 'exits from communism' linked with vectors of geography, social structure, ethnic composition and cultural values (Stark, 1996; King and Szelényi, 2005). Despite incongruities over the speed and sequencing of reforms and differing degrees of lenience towards institutional configurations between state, market and enterprises, the two sets of perspectives simply articulated different visions of (neoliberal) capitalism, rather than any substantial critique of it (Shields, 2012: 23-35). 
Meanwhile, the comparative European political economy literature has been dominated for some time by the Varieties of Capitalism (VoC) approach. It is argued that the way national political economies respond to external pressures is mediated and shaped by their particular national institutional set-ups. In Hall and Soskice's (2001: 8-9) original formulation, the analysis led to the development of a dichotomy between ideal types of national political economies: liberal- and market-coordinated economies. Responding to the inconclusiveness of debates over the speed and sequencing of liberalisation, privatisation and deregulation reforms, VoC literature also engaged with the 'post-communist' orbit. It questioned the utility of transferring the Western European bipolar typology ('liberal' or 'coordinated') into the geographies further East and generated discussions about the desirability (and limits) of multiplying ideal-typical subdivisions to account for national institutional variegations as well as the significance of political, ideological and cultural analytical coordinates (Lane and Myant, 2007). In addition, VoC scholarship grappled with the role of the state, agencies of 'elites' (and far less often, labour) and the nature of 1989 revolutions in configuring reform outcomes, with a handful of contributors addressing questions of how to conceptualise capitalism (e.g. Norkus, 2012; Bohle and Greskovits, 2012).

While the VoC literature has allowed us to understand the institutional diversity in CEE, it ultimately falls into the trap of 'methodological nationalism', conflating 'society with the state and the national territory and takes it as the unit of analysis' (Pradella, 2014: 181). While divergent economic performances are related back to institutional differences at the state level, what is not understood is the way economic performance in one country is closely related to economic development in other countries. This approach is conceptually unable to examine the dynamics of the European political economy as a whole. The institutional reductionism involved in externalising institutions as relatively isolated from and independent of each other, 
does not allow for grasping the historical specificity of capitalism and makes the economic and the political appear as separate.

By contrast, in this article it is argued that only through a historical materialist focus on the social relations of production is it possible to identify what exactly is specific about the capitalist historical period and the apparent separation of the economic and the political (Bieler and Morton, 2018: 3-23). This assertion is attached to a philosophy of internal relations, which implies that the character of capital is considered in terms of the internal ties between the relations of production, state-civil society, and conditions of class struggle (Ollman, 1976: 48). As a result of production being organised around wage labour and capitalist control and ownership of the means of production, the extraction of surplus labour is not directly politically enforced, because those who do not control their means of production are at least theoretically 'free' to sell their labour power. However, without owning one's own means of production, people are indirectly forced to look for paid employment in order to reproduce themselves. Thus, to understand the exploitation characteristic of capitalism, we "must explore the netherworld of production, outside and beneath the market, where economic necessity compels workers owning only their labour power to seek employment' (Barker, 2013: 44).

From the way in which production is organised around wage labour and the capitalist ownership of or control over the means of production, three structuring conditions can be identified. First, it is not only workers who compete with each other for employment. Because employers have to reproduce themselves through the market too, they operate in direct competition with each other towards a constant increase in profit levels:

There is only one basic driving force which compels capital in general to step up capital accumulation, extraction of surplus value and exploitation of labour, and feverishly to look for profits, over and above average profits: this is competition (Mandel, 1970: 26-7). 
Hence, the related pressure for further technological innovation in a relentless struggle for ever higher profit levels. Nevertheless, what is logical for the individual capitalist, is problematic for capital as a whole. When every capitalist attempts to produce more goods with fewer workers through the application of new technology, there will be fewer and fewer people, who can actually buy those goods. Thus, there is a situation of a surplus of both capital and labour, which can no longer be brought together in a productive way within the capitalist social relations of production, a 'state of overaccumulation' (Harvey, 1985: 132). Capitalism is thus characterised by a crisis tendency as a further structuring condition.

Finally, in order to overcome crisis, there is a necessity of constant outward expansion either in order to capture new markets or cheaper labour abroad or to re-commodify areas, which had been moved outside the capitalist market, such as health services in many industrialised countries (Bieler and Morton, 2018: 38-41). Structurally, this outward expansion is driven by processes of uneven and combined development. We follow Alex Callinicos' emphasis on the specificities of uneven and combined development within the capitalist mode of production (Callinicos and Rosenberg, 2010). Hence, 'capitalist expansion is a dynamic but also an uneven process, and in contrast to the neo-liberal (and pro-globalisation) positions, this unevenness is not seen as a result of market imperfections, but is in fact a product of the way competitive markets work in the real world' (Kiely, 2007: 18).

EU enlargement towards CEE has proven to be an ideal opportunity for outward expansion, helping in overcoming economic recessions in the early 1990s. Rather than mirroring the fantasy of a unilinear blueprint with all countries reaching the same level, development across the EU had been highly uneven over the last decades. From the outset, the mode of subordinate integration of 'ex-communist' economies into global capital circuits characterises the structural constellations of the region's neoliberal restructuring. At the heyday of the Washington Consensus, ingredients of an 'appropriate' transformation strategy entailed 
rapid macroeconomic stabilisation, the privatisation of formerly state-owned enterprises and the liberalisation of prices and trade. In lieu of Comecon, neoliberal forces at home and abroad promoted the region's absorption into the Western economic sphere based on the idea of a 'hub-and-spokes model' in which each state was to relate to others principally through its relationship with the Western hub (Gowan, 1995). With more complex 'communist-era' sectors deprived of former markets in the East, those that retained a competitive edge were precluded from accessing Western markets (protectionism under 'Europe Agreements'). Moreover, all ‘transition economies' were soon flooded with finished Western products.

In this process of uneven and combined development, states were compelled to compete for subcontracting agreements and foreign direct investment (FDI) by fashioning enticing investment climates oftentimes concomitant with downward pressure on wages and taxation (Drahokoupil, 2008). West European capital has benefited greatly from this unevenness between the old EU member states and the new members from CEE. By integrating suppliers from low wage CEE countries in their transnational production networks, multinationals reduced their wage costs considerably through whipsawing tactics that put subcontractors and workers from different locations in competition against each other. For example, CEE 'footwear producers now specialize, primarily, in labour-intensive activities, importing and assembling inputs according to the designs and specifications of Western European lead firms' (Selwyn, Musiolek and Ijarja, 2019: 11). German multinationals in general profited most from the availability of a cheap and well-trained industrial labour force establishing themselves predominately in the Czech Republic, Poland, Hungary, and Slovakia and used relocation threats to obtain concessions at home (Bohle and Greskovits, 2012: 161-172). In turn, a notable part of Southern Europe's low-cost industry moved to the EU's South-East, where wage-levels are as low as in China (Stan and Erne, 2014). They were joined by the Taiwanese TNC Foxconn, which established a number of production sites across CEE from 2000 onwards 
drawing on available cheap labour in the region (Sacchetto and Andrijasevic 2015; Andrjiasevic et al., 2020).

Some countries succeeded in 'technological upgrading' by linking up with multinationals, primarily in the motor-vehicle sector. In the Czech Republic, for instance, Volkswagen's acquisition of Škoda has led to an increased volume of car production and research and development activity as well as the retention of the new model development base in the country (Myant and Drahokoupil, 2011: 287). What made the three Baltic states 'exceptional' was not so much the achievements in securing investments in higher value-added sectors, but their ability to develop institutional landscapes to lure foreign capital in, with most of it actually ending up in financial intermediation, real estate, retail and telecommunications. In these sectors, FDI-induced benefits are far less pronounced. The pursuit of what Bohle and Greskovits (2012: 96) label a 'radically' neoliberal approach to 'transition' is reflected in the Baltic's largely unexcelled performance in the World Bank's Ease of Doing Business Index, United Nations Conference on Trade and Development's (UNCTAD) Transnationality Index or the Heritage Foundation's Index of Economic Freedom. What escaped the analytical compasses of those affording such accolades have been the concomitant extremely exploitative conditions of work. In short, this variegated integration into the European political economy has put workers in rather different positions within the global social relations of production, thus creating major obstacles for transnational labour solidarity.

Although outward expansion is a structuring condition of capitalism, the exact way this is played out depends on agency, involved in moments of class struggle. Starting our analysis through a focus on the capitalist social relations of production facilitates the identification of key collective agency. In order to grasp the internal relations between structuring conditions and class agency, the empirical focus has to be on class struggle between owners of the means of production and those 'free' to sell their labourr power. As a result, 
development is not presented only in 'economic terms', but as a social and political process that is co-determined by class struggle. Only by bringing labour — or, better, workers — back in, therefore, is it possible to overcome the roots of methodological nationalism and identify the underlying tendencies of the international political economy' (Pradella, 2014: 191).

In this article, labour is brought back in to re-assess 'post-communist' transformation within the historical specificity of capitalist exploitation.

\section{The double exploitation of 'post-communist' labour}

The manner in which uneven and combined development has unfolded in CEE is twofold. On the one hand, CEE countries' development has been combined with Western European countries' by providing cheap labour for work in global value chains as well as new areas for consumer spending often based on credit. On the other, CEE countries have provided Western European countries with cheap migrant labour. As Jane Hardy (2015: 190) argues, 'migration is constitutive to capitalism in the context of uneven development, in that it both shapes and is shaped by it'. In the following, first the implications for the labour markets in the Baltic countries will be assessed. Then, the plight of CEE migrant workers in the West and here, especially in the UK, is analysed.

\section{Netherworld of production during transformation cataclysm}

Over the course of transformation, Baltic labour regimes have become synonymous with casualised and informal types of employment, simultaneous lengthening and intensifying of work and deteriorating workplace environments (Sommers and Woolfson 2014; Woolfson, 2007a; 2007b; Woolfson, et al., 2008). The drive towards labour market deregulation proceeded in the milieu of dramatic sectoral restructuring induced by opening up to global market competition. The Organisation for Economic Co-operation and Development (OECD) 
(2000: 236-7) estimates that in the period from 1989 to 1998, the proportion of the workforce employed in industry and construction declined in all three states, with the former contracting precipitously in Latvia (28\% to $18 \%$ ) and Lithuania (30\% to $20 \%$ ). Numerically, employment contractions were colossal in industries related to the production of inputs and engineering. From 1990 to 1997 alone, employment dropped by 74,000 in Baltic machinery and metal production, by 62,000 in textile industries and by 19,000 in chemical and fuel manufacturing. While from 1989 to 1998 the proportion earning a living from land remained stable in Latvia and Lithuania and were to nosedive only later, by 1998 only $10 \%$ of Estonia's employment remained in the agricultural sector. Substituting for these declines was a marked expansion of service sector employment based on non-standard working arrangements.

Promoting a labour market liberalisation agenda, the World Bank, the OECD (Jobs Strategy) and the EU (European Employment Strategy) emerged as institutional mouthpieces for policy change. States in the region were coercively invited to reduce the costs of workers' dismissal, slash 'above productivity' minimum-to-average wage ratios below an 'artificially high' $40 \%$ mark, rectify 'imbalances of power' between trade unions and employers' organisations, abandon 'disincentivising' passive labour market policies, and deflate 'large number of beneficiaries' of social support programmes (Rashid et al., 2005: 65-9). At its extreme, the deregulation drive permitted capital's refusal to enter into any formal contracts with labour. Hence, approximately $8 \%$ of the workforce in Latvia, $11 \%$ in Estonia and $13 \%$ Lithuania had no formal contract as late as 1998 (Eamets and Masso, 2005: 81). Fixed-term contracts also expanded: in Latvia they constituted $23 \%$ of total employment agreements by 2002, compared to the 10\% EU average (Paoli and Parent-Thirion, 2003: 18). Part-time and self-employment arrangements proliferated, and a relatively high and stable proportion of labour was obligated to earn subsistence in multiple jobs. Likely underestimated figures show that $4.9 \%$ of Lithuanian, $6 \%$ of Latvian and $6.1 \%$ of Estonian workers had an additional job in 
2016 (Eurostat, 2019). The rhetoric of autonomy and flexibility was used to depict 'selfemployment' as an attractive 'choice' both in higher and low value-added sectors. Further, many occupying relatively stable positions in the private sector experienced informalisation due to a common employer practice to pay officially only a minimum wage alongside a supplement in the form of unreported compensation ('envelope wage'). These discretionary measures subject workers to near-total managerial control, enabling arbitrary wage reductions in cases of 'underperformance'. Additionally, 'envelope wages' are used as a 'soft' form of 'employee differentiation', allowing capital to eliminate staff no longer required without extra costs in terms of redundancy pay. Workers are forced to collude in the receipt of undeclared remuneration because of the fear of jeopardising their employment (Woolfson, 2007a: 555; Franić, 2019). As of 2007, one in eight Baltic workers received 'envelope wages', compared to one in twenty in the EU, consisting of approximately $45 \%$ of gross salary (Williams, 2009: 293). Such undeclared economic activity was not a mere Soviet-era remnant but integral to the restructured capital accumulation regimes. In 2017, the 'shadow economy' indexes, which measure misreported business incomes, unregistered or hidden employees and envelope wages in the proportion to countries' gross domestic product (GDP), exceeded 18\% in all three states, with most important components being underreported salaries and incomes (Putniņš and Sauka, 2018).

The deregulatory effort translated into pushed-up rates of exploitation, subjecting Baltic workforces to a punitive juxtaposition of higher work intensity and lengthened durations of work. Labour force surveys in Estonia and Lithuania indicate a rise in the annual working hours after 2004. In 2006 Estonia ranked fifth in the EU (with an average of 1,942 hours per year) recording an $0.5 \%$ increase compared to 2000 , despite a 25 percentage point increase in hourly productivity (GDP per hour worked) throughout the same period. A small $(0.5 \%)$ increase in Lithuania (1,855 hours per year), the tenth highest score, has been similarly counteracted by a 
30-percentage point rise in GDP per hour worked (OECD, 2019). Even if in Latvia annual hours worked registered a $2.6 \%$ decrease $(1,893)$, this was still the sixth highest score in the EU and had taken place against the backdrop of hourly productivity increases of more than a third from 2000 to 2006 (Morley and Sanoussi, 2009).

The severity of exploitation is corroborated by worker testimonies in the Sixth European Working Conditions Survey published in 2015 (Eurofound 2019). In the realm of posturerelated risks, over a third of Latvian (38\%) and Lithuanian (36\%) workforces characterise their employment environments as involving frequent carrying and moving of heavy loads. Not only do these figures attest to the second- and fifth-highest scores in the EU respectively, but 39\% of Latvian, $58 \%$ of Estonian and $60 \%$ of Lithuanian respondents described the labour process as involving monotonous and repetitive tasks (Eurofound, 2019). Furthermore, the latter group is disproportionately exposed to inhaling smoke and toxic vapours as well as handling chemical products and infectious materials, namely, the risk categories that accounted for almost half of work-related deaths in the EU in 2008 (Eurofound, 2017: 44). Against such backdrops of deteriorating employment conditions and adverse workplace environments, which worsened still further during the global economic and financial crisis, Baltic labour searched for escape routes (Sommers and Bērziņš, 2011; Sommers and Woolfson 2014). Many withdrew from home labour markets altogether, in the expectation of more accommodating conditions in Western Europe. To use the figurative phraseology of some local trade unions, Baltic airports have become the most active sites of 'protest'.

\section{Chains of European migration and capital's thirst for labour from the East}

The eastward enlargement of the European labour market has added an additional layer of unevenness, characterising the continent's division of labour by engendering a split between 'sender' and 'receiver' countries. Herein, the new EU members from CEE have occupied centre stage, registering negative demographic developments and waves of emigration to Western 
Europe. In turn, some have encountered severe labour shortages that were filled with imports of migrant labour from countries further East, notably Ukraine. According to the CEE Development Institute (Duszczyk and Matuszczyk, 2015: 13), compared to 2004, by 2013 Latvia registered an estimated $513 \%(23,000$ to 141,000$)$ increase in the number of citizens residing in the EU-15, with similarly numbers observed in Lithuania (436\% - 50,000 to 268,000), Romania (325\% - 541,000 to 2.3 million) and Poland (210\% - 580,000 to 1.8 million). As many as $11.6 \%$ of Romanian, $9 \%$ of Lithuanian, $8 \%$ of Croatian and $7 \%$ of Latvian nationals were estimated to reside in the EU-15 (see also Żuk and Żuk, 2018: 103). While on the part of some sections of capital in the 'sender' countries, these developments engendered demands for liberalisation of immigration policies, state managers in worst crisis-hit states described the labour exodus and plummeting birth and family formation rates as a "natural course of events'. Workforce exportation helped externalise social tensions arising from high unemployment and reduced balance of payments deficits through incoming remittances. As can be inferred from the previous section, for Eastern European labour, geographical mobility has been enveloped in very different meanings associated with ventures to escape the plights of low wages, precarity, unemployment and the undermining of dignity, as well as an opportunity, however elusive, to bolster strained family budgets by sending money back home. If such motivations to emigrate are a clear element of European socio-economic development, what accounts for capital's eagerness to recruit migrant workers?

For Marx (1867/1990: 1013), the logic of capital's operation is inseparable from its inclinations to abolish 'all laws preventing the labourers from transferring from one sphere of production to another and from one local centre of production to another' and to overturn 'all legal barriers that would prevent it from buying this or that kind of labour'. Yet, if free spatial mobility of labour-power is a necessary pivot of accumulation, it is simultaneously checked by capital's desire to keep labour reserves in place and is further mediated through selective 
oscillations between support and opposition for policies that eliminate racial, sexual, and religious discriminations in labour markets (Harvey, 1982/2006: 382). In our considered cases, this selectivity has manifested itself in the restricted rights of East European workers to move freely within the EU in the aftermath of eastward enlargement by most of the old member states.

The free movement of persons not only implied an economic dimension but also constituted an essential part of EU citizenship rights, both of which were withheld from the nationals of the new member states for up to seven years (Bohle, 2006: 70). Similarly, the United Kingdom's (UK) immediate post-accession opening up of the labour market for Eastern European migrant workers had nothing to do with notions of philanthropy or hospitality. Instead, it reflected a shortage of labour in low-wage sectors, something not repeated with similar haste for counterparts from Bulgaria and Romania three years later. Sections of the ruling class have been far from united in their views on immigration, as the debate around Brexit illuminates. The division between segments that do not derive benefits from migrant labour and are therefore unwilling to bear the associated costs and those keen to defend the benefits of migration, has been fuelled by reports offering contradictory findings on the link between immigration and depressed wages or increased unemployment (Hardy, 2009a). On one hand, the House of Lords' Economic Impact of Immigration (2008) inquiry and publications such as the Bank of England's The Impact of Immigration on Occupational Wages study (Nickell and Saleheen, 2015), indicating that a 10 percentage point increase in immigration reduces wages by an equivalent of $2 \%$ for semi- and un-skilled service sector workers, have supplied points of reference to sections opposing 'free movement'. On the other, reports like the one produced by the London School of Economics' (LSE) Centre for Economic Performance (Wandsworth et al., 2016: 16) provide evidence to the contrary, while the recent 
study by the Migration Advisory Committee (2018) claims that migrants have no or little impact on the overall employment and unemployment outcomes of the UK-born workforce.

In our view, these studies dubiously frame the debate around the question of presence or absence of migrants' responsibility for wage depression. For one, this detaches the effect of migration on employment conditions from intervening factors such as the intensity of capitalist competition, management's need to balance investing in skills against suppressing wages and crucially, working class ability to resist exploitation across sectors and in specific workplaces. Furthermore, the discourse on lower remuneration becomes abstracted from neoliberal flexibilisation of labour markets, forgetting not only that processes of privatisation, outsourcing and subcontracting have intensified competition in industries such as cleaning, construction and other badly paid service sector jobs (distribution and supermarkets) and predated the arrival of Eastern European workers by decades (Hardy, 2009a; 2009b). Finally, it assumes that in the absence of migrants, capital would employ 'national' workers at the 'historical value' of their labour-power thus significantly increasing their remuneration.

For capital, migrant labour fulfils the function of the 'reserve army' employable in the periods of expansion and easily dischargeable in moments of stagnation, whilst also constituting the means to increase the degree of exploitation. The very unsteadiness of capital accumulation mandates the requirement for a readily available labour surplus, which can be augmented through importations and relocations of living labour. The 'reserve army' also counteracts the tendency for wages to rise (and the rate of profit to fall) that would threaten the extraction of surplus value.

That migrant labour constitutes an invaluable resource to increase the degree of exploitation and thereby raise the rate of surplus value can be inferred from the propensity to recruit Eastern Europeans in food processing, hospitality and agriculture, the sectors that are experiencing major problems filling job vacancies and tend to be those most exposed to 
competitive pressures. Excessive working hours, inadequate duration of breaks, bullying, problems with obtaining employer references, disproportionately high fees imposed by recruitment agencies for job search, as well as instances of lower-than-agreed (below the National Minimum Wage) remuneration and withholding of wages have been widely documented. Given the young profile of CEE migrant workers (81\% were aged between 18 and 34 in 2008), employers can subject this segment of the working class to worst possible health and safety conditions and stockpile savings related to the organisation of work (Fitzgerald and Hardy, 2010: 132). Migrant women, who upon entering the country do not qualify for social support for protracted durations, suffer disproportionately from workplaceand (oftentimes) household-based exploitation that intertwines with sexual discrimination, including unfair and non-compensated lay-offs over pregnancy or 'unacceptable' clothing requirements.

As indicated by a migrant coordinator at the Irish Congress of Trade Unions, the many cases alleging exploitation and unfair dismissal, suggest labour rights standards in Northern Ireland might even be lower than in Poland or Slovakia (cited in McDonald 2008: 18). More broadly, the East European Resource Centre found that in 2016, 82\% of Eastern European households in the UK earned less than GBP 10,000 per year and in 2013, of those living in London, a fifth encountered constant and serious financial struggle and almost a third lacked money for food, medicines, bills and other essentials at least once (Dorodowicz, 2018; Eastern European Resource Centre, 2013; 2017). Chronicles of tied-accommodation wherein employers make migrant workers indebted prior to their arrival by charging extortionate bus fares and then provide over-priced 'housing' in the form of shared mattresses used for sleeping in shifts are signs of extensive exploitation (Moore, 2017).

In this connection, the UK's departure from the EU reinforces the pressures on employment and living conditions. Capital's fuelling of the anti-immigration discourse 
intimidates workers from 'ex-communist' states by pitting them against other ethnic minority colleagues. Employers have increasingly used the reference to Brexit in order to withdraw job offers underscoring uncertain immigration status, and also to justify wage decreases, and the withholding of annual leave and sickness pay (Dorodowicz, 2018). And yet, while the general lack of security delineates the contours of émigré everyday life, it would be erroneous to see Eastern European labour merely as the object of capital's exploitation. Workers have not simply accepted these developments. The next section unearths moments of resistance against intensified exploitation.

\section{Cartographies of Eastern European labour's resistance}

Far from amounting to the bundle of muscles to which capital readily resorts on a daily basis, workers are subjects in the human sense, whose energy, cooperation and imagination are indispensable personal values that can be channelled into deeds of collective struggle (Dale, 1999: 9). We posit that the disintegration of the Soviet Union did not constitute a universal setback for emancipatory struggles (Amin, 2016: 81-106) nor induced acquiescence on the part of labour movements in the East (Ost, 2006). While such accounts do indeed capture the ferocity of capital's onslaught against labour in the cataclysm of transformation and beyond, at times they tend to skip over important instances of class struggles from below. Therefore, the task of great pertinence is to re-approach and unearth oft-forgotten and undocumented workplace struggles as well as broader protest actions, wherein 'post-communist' labour actively fought against the travails of capitalist exploitation at home, abroad and across national borders. We sketch three noteworthy instances of CEE labour's resistance, with the hope of generating avenues for more ambitious research enquiries.

\section{Bringing 'post-communist' labour struggles back on the radar}


It is easy, relying on indicators such as low trade union densities, collective bargaining coverages and strike rates among the Eastern European EU member states, to proclaim the demise of labour solidarity. Highlighting the individualised and employer-driven nature of Baltic industrial relations, commentators posit the relegation of organised labour to the public sector, where it plays only a minimal role in the national-level social dialogue (Gonser, 2011). Agreeing with such a diagnosis only in part, we contend that the empirical record challenges the reduction of labour's agency to that of a passive bystander to the unfolding drama of neoliberal restructuring. The following brief illustration with reference to Lithuania is telling.

What emerges from the various issues of narrowly circulated independent labour weekly Opozicija is a rich mosaic of labour and societal unrest that followed immediately after the launch of 'Shock therapy'. In 1993 alone, the education workers' trade union engaged in nationwide industrial action, managing to secure an eight-fold wage increase over twenty-four months. Similarly, tertiary workers' demonstrations and strikes against the privatisation of their enterprises provoked the government's response in solidifying the preferential treatment of employees in obtaining shares at discounted rates (initial prices) in the first auction round of the country's 'mass' privatisation programme. Thus, if in 1991 such preferential treatment applied to $10 \%$ of enterprise stock, following the protest wave it was extended to $50 \%$ (Šimènas, 1997: 64). This is not to suggest that the solution proved beneficial in the long-run, nor to fantasise that the proportion of shares translated into voting rights. However, that the segment of enterprises, where employees and managers controlled the majority of shares rose from 3\% in 1992 to $92 \%$ in 1995 is an indication of labour's capacity to configure 'transition' trajectory (Mygind, 1997: 143).

Additionally, in the spring of 1993, in Lithuania, pickets against rising food prices, uniting workers, pensioners, students, unemployed and disabled persons, took place at the parliament square, which also became the meeting point for mass demonstrations over wages and 
unemployment as well as the European-wide 'right to work' campaign. While in May the transportation system in Lithuania's third-largest city of Klaipedda was brought to a standstill due to a three-week strike, a month later protestors organised a tent camp 'against the destruction of Lithuania's industry' in front of parliament.

More recently, sectors without previous histories of organising became the epicentres of labour unrest. For instance, the cashiers of one shop belonging to the Palink-IKI supermarket chain (controlled by German REWE Group) struck in August 2007. This primarily female-led mobilisation accentuated precarious conditions, very low pay, wave of redundancies and cuts in almost all extra motivation payments (accounting for $30 \%$ of decrease in income) as the main reasons for industrial action (Donauskaitè, 2009). Whilst triggering management's retaliatory response that included harassment, intimidation and layoffs of union activists, the campaign also attracted media and parliamentary attention, shedding light on repressive working environments.

A year later, alongside individual unions in different supermarkets, the first sectoral service workers trade union was established, sounding the death knell to the sector's unionfree reputation. In 2016, meanwhile, the Lithuanian labour scene has witnessed the establishment of the social movement 'Life is too expensive' (Gyvenimas per brangus), fighting to defend the rights and conditions of workers, tenants and students. Over that year, activists boycotted supermarkets over price-hikes and low wages, organised flash-mobs highlighting precarious employment conditions in retail trade, held city- and neighbourhoodassemblies uniting students, pensioners and service sector workers and resisting Labour Code liberalisation. They staged occupations in two of the country's largest cities that attracted broad public support. The outgrowth of these organisational efforts has been the newly founded G1PS trade union (Gegužès 1-osios profesinè sajunga), which stands out from its counterparts due to the emphasis on class struggle as opposed to a class compromise-led politics of tripartism. 
Espousing the principles of class solidarity that extends to other forms of oppression, the union also defines 'resistance' open-endedly to include mobilisations against rising prices of food, rent or living expenses, the fight for widely available and quality healthcare, education and other public services. In many ways, initiatives such as these serve as a useful corrective to postulations about the alleged quiescence of organised labour in Lithuania.

\section{Approaching resistance against capital abroad}

When addressing the conditions of work and life of Eastern European labour in Western Europe, it is imperative, together with Hardy (2009a), to contest an assumed hierarchy of nationalities regarding proneness towards political activity, and to challenge the alleged hopelessness of organising precariously employed migrant workforces. Evidence shows that just as their counterparts from elsewhere, Eastern Europeans are far from inimical to trade union organising abroad. On this register, trade unions in the UK and Ireland have played a pioneering role in reaching out to Eastern European migrants via developing international linkages and adopting innovative organisational strategies. Cooperation with Polish counterparts - Solidarity, which to great dismay has recently sided with the right wing populist Law and Justice party in endorsing anti-immigrant slogans at home (Żuk and Żuk, 2018: 110-11), and OPZZ - were particularly effective in posting organisers that helped facilitate the recruitment of activists among migrants. Solidarity's use of internet promotions to encourage departing workers to unionise in the UK has been complemented with the TUC members' attendance at job fairs in Warsaw and the pressure for local unions to develop Polishlanguage website sections and application forms (Campbell, 2006). Innovative organisational methods included forging of partnerships with ethnic associations (Polish Catholic Association in Birmingham) and founding Polish-language union sections in Southampton and Glasgow by the General, Municipal, Boilermakers (GMB) union and Transport and General Workers' Union. They extended to active campaigning on employment rights in Temporary Work 
Agencies, efforts to familiarise migrants with labour law and skill-development initiatives through qualification recognition and English language training (Meardi, 2012: 109-110). One recent example of successful recruitment is the Bakers Food and Allied Workers Union's Midlands branch, whose 6000 strong membership includes about 1000 Eastern European workers (Chaffin, 2017). In 2006, the same union concluded a far-reaching agreement with an employment agency in the UK, allowing it to audit comprehensively the recruitment of Polish workers and encourage unionisation (Hardy, 2015: 195).

To varying degrees, these creative tactics have inspired union organising activities in the Netherlands, Germany, Finland, Denmark, Norway and Sweden, most notably in the construction sector. In consequence, Eastern Europeans stood on the picket lines shoulder to shoulder with their colleagues, including migrant workers from Latin America and the Caribbean. Industrial action at the Iceland distribution warehouse in Enfield, pay and pension disputes with First Bus in the Midlands, as well as demonstrations alongside Irish workers in protest to management's recourse to migrant recruitment on worse pay and employment conditions, are cases in point (Hardy, 2009b: 160-161). Recent examples also include the UNITE-led cleaners, porters and security staff mobilisation at the Barts National Health Service (NHS) trust network of London hospitals, when their contracts were outsourced to Serco multinational. Facing excessive workload and heightened work intensity, the mostly immigrant workforce numbering around one-thousand called for a fair and proper pay rise of GBP 0.30 an hour, launching a three-day walkout in July 2017, followed by consecutive work stoppages (Tengely-Evans, 2017). In May 2018, it was the warehouse operatives, drivers and office staff, who went on strike at Tesco Dagenham distribution centre demanding $15 \%$ pay increase. Organised by the Union of Shop, Distributive and Allied Workers, most were taking part in industrial action for the first time. The sizeable proportion of Eastern European workers 
has been described as devoted and vocal, at times even shaming picket crossers in their own languages (Campanile, 2018).

\section{Towards transnational solidarity}

Eastward enlargement of the EU proved to be a challenge to transnational solidarity from the very beginning. As a result of uneven development, working conditions and wage levels were highly differentiated between Eastern and Western Europe. Workers and trade unions in the West feared the potential competition by their fellow CEE workers, who were often highly skilled, but had much lower salary expectations. Hence, West European trade unions, especially the Deutscher Gewerkschaftsbund (DGB) and Österreichischer Gewerkschaftsbund (ÖGB) pushed (successfully) for a transition period of up to seven years in relation to the free movement of labour. Otherwise, it would be difficult to maintain 'social Europe' and guard against the rise of right-wing parties fuelled by popular unrest, they argued (Bohle and Husz, 2003: 96-106). This political victory, based on a lack of transnational solidarity, however, contributed to regime competition between Eastern and Western European labour movements, undermining labour in both areas of the EU. Despite moments of solidarity in subsequent years, trade union co-operation had been placed on a difficult footing from the very start of EU enlargement.

It is often assumed that areas of transnational production are those most easily susceptible to strategies of transnational solidarity. Trade unions, organising workers in transnational production sectors, were the first to realise that, at the national level, they were no longer able to keep wages and working conditions impervious to capitalist competition. In the case of General Motors (GM) production sites in Europe, however, despite frequent attempts to organise the workforces across all sites so that GM could not put them into competition with each other, Polish trade unions rejected demands for solidarity and negotiated concession agreements with management (Bernaciak, 2010). Only when Polish workers felt secure in the 
profitability of their production sites, did they co-operate with workers from other countries. Nevertheless, direct competition does not automatically exclude transnational solidarity. More recent efforts at unionising the global retail giant Amazon provide a hopeful glimpse. Soon after workers had started to organise at German Fulfilment Centres (FCs), the company started to build three FCs across the border in Poland, from which it intended to carry out deliveries to German customers in times of strikes at German FCs. 'Amazon threatened more or less openly to relocate jobs from the strike-prone Germany to the neighbouring country to the east' (Boewe and Schulten, 2017: 25). Thanks to direct contacts between workers at German and Polish FCs, it was possible on occasions to engage in transnational solidarity. 'When employees at the Polish amazon FC in Poznan (POZ1) were told that their shifts would be extended by an hour at short notice at the end of June 2015, spontaneous protests broke out, resulting in a go-slow strike' (Boewe and Schulten, 2017: 29). They had realised that their extended shifts were supposed to counter the walkout at the FC in Bad Hersfeld, Germany.

In the traditional public sector, workers do not directly compete with each other over jobs. As a result, it may be easier to establish transnational solidarity and also co-operate with other social movements (Bieler and Lindberg, 2010: 224). The European-wide campaign 'Water is a Human Right' is a good example in this respect. Co-ordinated by the European Federation of Public Service Unions (EPSU) at the European level, between May 2012 and September 2013 close to 1.9 million signatures were collected across the European Union (EU) in support of the first European Citizens' Initiative on this issue. Amongst the successful countries, in which the required quota of signatures had been reached, were also Hungary, Lithuania, Slovakia and Slovenia from CEE. Both the Lithuanian campaign, led by the Lithuanian Industry Trade Unions' Federation, and the Slovenian campaign, led by the Trade Union of Energy Sector Workers, had strong trade union as well as social movement involvement (Bieler, 2017: 31011). Thus, the common interest over access to clean water, which needs to be secured at the 
local and national level and thus does not imply direct competition between different national labour movements, made it easy to cooperate across the EU in this particular area of services. In short, while not the norm, transnational solidarity within the EU between labour movements in East and West is possible.

\section{Conclusions}

What three decades ago was celebrated as a great victory of revolutionary change in the realms of democracy and the market soon came to exhibit the renewed contours and geographies of intensified exploitation. Having first encountered global market competition through the restructuring of labour regimes, and ensuing deteriorating workplace environments, the majority of Eastern European workers were disappointed in their sanguine expectations of escaping the plight at home through outward migration. Capitals based in Western Europe used this segment of migrant labour to raise the rate of surplus value via recruiting it in the sectors most exposed to competitive pressures. Yet, the twin dynamics of exploitation should not be taken to imply that the CEE region as a whole denotes nothing else but a social wasteland where capital dominates labour. Nor is there some pre-existing hierarchy of nationalities according to which some are more prone than others to organising around the demands for social justice. Postulations about alleged 'post-communist' labour's quiescence tend to discount the many instances in which those workers actively contested capitalist exploitation at home, abroad and across national borders.

The present conjuncture, whereby capital is forced to seek resolutions to its multiple crises through 'authoritarian populist' responses, warns us not to overstate the extent of resistance, nor to idealise uncritically the potentials for working class mobilisation in the direction of emancipatory futures (Dale and Fabry, 2018; Kalb, 2018; Żuk, 2017a; 2017b). Pressing quandaries remain: sharply contracted union density since the onset of transformation; and 
subpar rates of collective bargaining coverage, linked that to its concentration at the enterprise level and its predominance in the public sector. The undermining of workers' bargaining power in the light of proliferating non-standard employment arrangements, the persistence of union fragmentation along political lines as well as the populist anti-democratic right's capacity to articulate illusionary imaginaries of 'social justice', present further challenges.

That ever more states in the region emerge as epitomes of this 'authoritarian populist' predicament, with Estonia, once the posterchild of neoliberal restructuring being the most recent case in point, invokes reasons for pessimism and signals the urgent need to search for progressive alternatives. To stand any chance of being successful, this task cannot be detached from re-articulated histories of struggle, some of which this article has sought to unearth. It is also pertinent to recall that the electoral breakthroughs for both neo-fascist parties and former centre-right formations now readily espousing an extreme-right agenda do not stem from the presumed 'institutional democratic weakness' of CEE polities or the 'lack of post-materialist values' among the region's populations (Sierakowski, 2018). What they do mirror, as Gavin Rae (2018) indicates, are the defeats of the Eastern European left, owing not to its association with the previous system per se, but, instead owing to its espousal of the 'third way' politics in the early 1990s. Reimagining and scaffolding the left project in Eastern Europe not only has to be firmly rooted in the moments and politics of class struggle but also capable of articulating demands beyond capitalism through bottom-up initiatives. Among others, platforms in Poland (municipal movements and Razem), Romania (Demos), Slovenia (Levica), Latvia (Progresīvie) or Croatia (Zagreb je $N A \check{S}$ ) already indicate the initial movement in this direction. 


\section{References}

Andrijasevic R, Sachetto D and Pun N (2020) One firm, two countries, one workplace model? the case of Foxconn's internationalisation. The Economic and Labour Relations Review 31(1): https://doi.org/10.1177/1035304619880680.

Amin S (2016) Russia and the Long Transition from Capitalism to Socialism. New York, NY: Monthly Review.

Barker C (2013) Class struggle and social movements. In: Barker C, Cox L, Krinsky J, and Nilsen AG (eds.) Marxism and Social Movements. Leiden, NL: Brill, pp. 41-61.

Bernaciak M (2010) East-West European labour transnationalism(s): rivalry or joint mobilisation? In Bieler A and Lindberg I (eds) Global Restructuring, Labour and the Challenges for Transnational Solidarity. London, UK: Routledge, pp.33-47.

Bieler A (2017) Fighting for public water: The first successful European Citizens' Initiative 'Water and Sanitation are a Human Right', Interface: a Journal for and about Social Movements, 9(1): 300-26.

Bieler A and Lindberg I (2010) Conclusions: A variable landscape of emerging transnational solidarities. In: Bieler A and Lindberg I (eds.) Global Restructuring, Labour and the Challenges for Transnational Solidarity. London, UK: Routledge, pp.220-31.

Bieler A and Morton AD (2018) Global Capitalism, Global War, Global Crisis. Cambridge, UK: Cambridge University Press.

Boewe, J and Schulten, J (2017) The long struggle of the Amazon employees. Brussels, BE: RosaLuxemburg-Stiftung. Available at https://www.rosalux.eu/publications/the-long-struggle-ofthe-amazon-employees/; accessed 16/07/2019.

Bohle D (2006) Neoliberal hegemony, transnational capital and the terms of the EU's eastward expansion. Capital \& Class, 30(1): 57-86.

Bohle D and Greskovits B (2012) Capitalist Diversity on Europe's Periphery. Ithaca, NY: Cornell University Press. 
Bohle D and Husz D (2003) Whose Europe is it? Interest group action in accession negotiations: the cases of competition policy and labor migration. CAIRN.INFO, 15: 85-112; available at https://www.cairn.info/revue-politique-europeenne-2005-1-page-85.htm; accessed 16/07/2019.

Bruff I (2011) What about the elephant in the room? Varieties of capitalism, varieties in capitalism. New Political Economy, 16(4): 481-500.

Callinicos A and Rosenberg J (2010) Uneven and combined development: the social-relational substratum of 'the international'? An exchange of letters. In: Anievas A (ed.) Marxism and World Politics: Contesting Global Capitalism. London, UK: Routledge, pp.155-88.

Campanile F (2018) The Tesco Dagenham Strike and the power of distribution workers, Notes from below, 20 May. Available at: https://notesfrombelow.org/article/tesco-workers-strikedagenham-distribution-centre (accessed 18 July 2019).

Campbell D (2006) Poles are bringing solidarity back into fashion in Britain. The Guardian, 6 December: 32 .

Chaffin J (2017) UK trade unions embrace Polish workers to boost membership. Financial Times, 1 May. Available at: https://www.ft.com/content/e104ea60-2e4e-11e7-9555-23ef563ecf9a (accessed 20 January 2020).

Dale G (1999) Introduction. In: Dale G and Cole M (eds), The European Union and Migrant Labour. Oxford, UK: Berg Publishers, pp. 1-10.

Dale G and Fabry A (2018) Neoliberalism in Eastern Europe and the former Soviet Union. In: Cahill D, Cooper M and Konings M (eds) The SAGE Handbook of Neoliberalism. London, UK: Sage, pp. 234-447.

Donauskaitė D (2009) IKI profesinè sajunga - kaip velniui kryžius [IKI trade union as a cross to a devil]. In Bielskis A (ed) Demokratija be darbo judejjimo? [Democracy without a Labour Movement?]. Vilnius, LI: Kitos Knygos, pp. 99-110.

Dorodowicz B (2018) Why some eastern Europeans are driven to sleep rough. In: LSE Brexit. Available at: https://blogs.lse.ac.uk/brexit/2018/01/25/why-some-eastern-europeans-aredriven-to-sleep-rough/ (accessed 18 July 2019). 
Drahokoupil J (2008) Globalization and the State in Central and Eastern Europe: The Politics of Foreign Direct Investment. London, UK: Routledge.

Duszczyk M and Matuszczyk K (2015) A One-way Ticket?: Migration in Europe from the Perspective of CEE Countries. Warsaw, PL: Central and Eastern Europe Development Institute.

Eamets R and Masso J (2005) The paradox of the Baltic states: labour market flexibility but protected workers? European Journal of Industrial Relations 11(1): 71-90.

East European Resource Centre (2013) East Europeans in London: A Peer Led Study of the Issues Faced by East Europeans in London Relating Housing, Employment, Household Income and Support Needs. London: EERC.

East European Resource Centre (2017) East Europeans at Work: Lessons from Outreach. London, UK: EERC.

Eurofound (2017) Sixth European Working Conditions Survey - Overview report, 2017 update. Luxembourg: Publications Office of the European Union.

Eurofound (2019) Sixth European Working Conditions Survey - Data Visualisation. Available at: https://www.eurofound.europa.eu/data/european-working-conditions-survey_(accessed 18 July 2019).

Eurostat (2019) Employed persons with a second job https://ec.europa.eu/eurostat/databrowser/product/view/TPS00074?lang=en (accessed 18 July 2019).

Fitzgerald I and Hardy J (2010) 'Thinking outside the box'? Trade union organizing strategies and Polish migrant workers in the United Kingdom. British Journal of Industrial Relations 48(1): $131-150$

Franić J (2019). Explaining workers' role in illegitimate wage underreporting practice: evidence from the European Union. The Economic and Labour Relations Review 30(3): 366-381

Fukuyama F (1989) The End of History? The National Interest 16: 3-18. 
Gonser M (2011) More of the same, but faster?-The financial crisis and the representation of employee interests in the Baltic States. Transfer: European Review of Labour and Research 17(3): 409-414.

Gowan P (1995) Neo-liberal theory and practice for Eastern Europe. New Left Review (213): 3-60.

Hall PA and Soskice D (2001) An Introduction to Varieties of Capitalism'. In: Hall PA and Soskice D (eds) Varieties of Capitalism: The Institutional Foundations of Comparative Advantage. Oxford, UK: Oxford University Press.

Hardy J (2009a) Migration, migrant workers and capitalism International Socialism, 122. Available at: https://isj.org.uk/migration-migrant-workers-and-capitalism/ (accessed 20 January 2020). Hardy J (2009b) Poland's New Capitalism. London, UK: Pluto Press.

Hardy J (2015) Explaining ‘varieties of solidarity': labour mobility and trade unions in an enlarged Europe. Transfer: European Review of Labour and Research 21(2): 187-200.

Harvey D (1982/2006) The Limits to Capital. London, UK: Verso.

Harvey D (1985) The geopolitics of capitalism. In Gregory D and Urry J (eds) Social Relations and Spatial Structures. London, UK: Macmillan, pp. 128-63.

House of Lords Select Committee on Economic Affairs (2008) The Economic Impact of Immigration.

Volume 2: Evidence. Available at:

https://publications.parliament.uk/pa/ld200708/ldselect/ldeconaf/82/82ii.pdf (accessed 2

February 2020).

Kalb D (2018) Upscaling illiberalism: class, contradiction, and the rise and rise of the populist right in post-socialist Central Europe. Fudan Journal of the Humanities and Social Sciences 11(3): 303-321.

Kiely R (2007) The New Political Economy of Development: Globalization, Imperialism, Hegemony. London, UK: Palgrave.

King LP and Szelényi I (2005) Post-communist economic systems. In: Smelser N and Swedberg R (eds) The Handbook of Economic Sociology. Princeton NJ: Princeton University Press, pp. 205-229. 
House of Lords (2008) The Economic Impact of Immigration Volume 1 Report. London, UK: House of Lord Select Committee on Economic Affairs, the Stationery Office. Available at https://publications.parliament.uk/pa/ld200708/ldselect/ldeconaf/82/82.pdf accessed $31 / 01 / 2020$.

Lane DS and Myant MR (2007) Varieties of Capitalism in Post-communist Countries. Basingstoke, UK: Palgrave Macmillan.

Lipton D and Sachs J (1990) Creating a market economy in Eastern Europe: the case of Poland. Brookings Papers on Economic Activity 1(1990): 75-147.

Mandel E (1970) The laws of uneven development New Left Review 59: 19-38.

Marx K (1867/1990) Capital: Volume 1. London, UK: Penguin Classics.

McDonald H (2008) Migrant workers in Northern Ireland too easy to exploit, claim unions. The Observer, 9 March: 18.

Meardi G (2012) Union immobility? Trade unions and the freedoms of movement in the enlarged EU. British Journal of Industrial Relations 50(1): 99-120.

Migration Advisory Committee (2018) EEA Migration in the UK: Final Report. London, UK: Migration Advisory Committee.

Moore J (2017) Migrant rentals squeezing life out of workers. The Sun, 27 September: 15. Morley J and Sanoussi F (2009) Comparative Analysis of Working Time in the European Union. Loughlinstow, IE: European Foundation for the Improvement of Living and Working Conditions.

Myant M and Drahokoupil J (2011) Transition Economies. Political Economy in Russia, Eastern Europe, and Central Asia. Hoboken, NJ: John Wiley and Sons.

Mygind N (1997) Privatisation and employee ownership: the development in the Baltic countries. In Hood N, Kilis R, and Vahlne JE (eds) Transition in the Baltic States. London, UK: Palgrave Macmillan, pp. 131-147.

Nickell S and Saleheen J (2015) The impact of immigration on occupational wages: evidence from Britain. Staff Working Paper No. 574, London, UK: Bank of England. 
Norkus Z (2012) On Baltic Slovenia and Adriatic Lithuania: A Qualitative Comparative Analysis of Patterns in Post-Communist Transformation. Budapest, HU: Central European University Press.

Ollman B (1976) Alienation: Marx's Conception of Man in Capitalist Society, Second Edition.

Cambridge, UK: Cambridge University Press.

Organisation for Economic Cooperation and Development (OECD) (2000) Baltic States: A regional economic assessment. OECD Economic Surveys. Paris, FR: OECD.

Organisation for Economic Cooperation and Development (OECD) (2019) GDP per hour worked Available at: https://data.oecd.org/chart/5CFv (accessed 18 July 2019).

Ost D (2006) The Defeat of Solidarity. Ithaca, NY: Cornell University Press.

Paoli P and Parent-Thirion A (2003) Working Conditions in the Acceding and Candidate Countries.

Loughlinstow, IE: European Foundation for the Improvement of Living and Working Conditions.

Pradella L (2014) New developmentalism and the origins of methodological nationalism. Competition \& Change 18(2): 180-93.

Putniņš, T and Sauka, A (2018) Shadow Economy Index for the Baltic Countries 2009-2018. Riga, LV: Stockholm School of Economics, Riga. Available at https://www.sseriga.edu/sites/default/files/201905/SSERiga_Shadow_Ecnomy_Index_2018_1.pdf accessed 31/01/2020.

Rae G (2018) Eastern Europe's right-wing shift is not unique. Social Europe, 12 March. Available at: https://www.socialeurope.eu/eastern-europes-right-wing-shift-is-not-unique (accessed 30 January 2020.)

Rashid M, Rutkowski J and Fretwell D (2005) Labor markets. In: Barr N (ed.) Labor Markets and Social Policy in Central and Eastern Europe, Washington, DC: World Bank, pp. 59-87.

Sacchetto D and Andrijasevic R (2015) Beyond China: Foxconn's assembly plants in Europe. The South Atlantic Quarterly, 114(1): 21524.

Selwyn B, Musiolek B and Ijarja A (2019) Making a global poverty chain: export footwear production and gendered labor exploitation in Eastern and Central Europe. Review of 
International Political Economy, online first:

https://doi.org/10.1080/09692290.2019.1640124 .

Shields S (2012) The International Political Economy of Transition: Neoliberal Hegemony and Eastern Central Europe's Transformation. London, UK: Routledge.

Sierakowski (2018) How Eastern European populism is different. Project Syndicate 31 January. Available at: https://www.project-syndicate.org/commentary/populism-stronger-in-easterneurope-by-slawomir-sierakowski-2018-01 (accessed 29 January 2020).

Šimènas A (1997) Lithuania's economy during the period of reforms (1990-1994). In Buračas A, Larson DM and Kairys JP (eds) Lithuanian Economic Reforms: Practice and Perspectives. Vilnius, LI: Margi Raštai, pp. 63-74.

Sommers J and Bērziņš J (2011) Twenty years lost: Latvia's failed development in the post-Soviet world. In: Dale G (ed.) First the Transition, then the Crash: Eastern Europe in the 2000s. London, UK: Pluto, pp. 119-142.

Sommers J and Woolson C (eds) (2014) The Contradictions of Austerity: The Socio-Economic Costs of the Neoliberal Baltic Model. London, UK: Routledge.

Stan S and Erne R (2014) Explaining Romanian labor migration: from development gaps to development trajectories. Labor History 55(1): 21-46.

Stark D (1996) Recombinant property in East European capitalism. American Journal of Sociology 101(4): 993-1027.

Tengely-Evans T (2017) Barts health trust strikers step up action to beat Serco, Socialist Worker,15 August. Available at: https://socialistworker.co.uk/art/45147/Barts+health+trust+strikers+step+up+action+to+beat+ Serco (accessed 18 July 2019).

Wadsworth J, Dhingra S, Ottaviano G, and Van Reenen J (2016) Brexit and the Impact of Immigration on the UK. London, UK: London School of Economics, Centre for Economic Performance.

Williams CC (2009) The prevalence of envelope wages in the Baltic Sea region. Baltic Journal of Management 4(3): 288-300. 
Woolfson C (2007a) Pushing the envelope: the informalization of labour in post-communist new EU member states. Work, Employment and Society 21(3): 551-564.

Woolfson C (2007b) Labour standards and migration in the new Europe: Post-communist legacies and perspectives. European Journal of Industrial Relations 13(2): 199-218.

Woolfson C, Calite D and Kallaste E (2008) Employee 'voice' and working environment in postcommunist New Member States: an empirical analysis of Estonia, Latvia and Lithuania. Industrial Relations Journal 39(4): 314-334.

Żuk P (2017a) Employment structures, employee attitudes and workplace resistance in neoliberal Poland. The Economic and Labour Relations Review 28(1): 91-112.

Żuk P (2017b) Non-alternative reality? On the misery of the Left in Eastern Europe: the case of Poland. Journal of Contemporary Central and Eastern Europe 25(1), 63-84.

Żuk P and Żuk P (2018) Offshoring, labour migration and neo-liberalisation: nationalist responses and alternatives in Eastern Europe. The Economic and Labour Relations Review 29(1): 97-117.

\section{Author Biographies}

Andreas Bieler is Professor of Political Economy at the School of Politics and International Relations at the University of Nottingham, and Fellow of the Centre for the Study of Social and Global Justice (CSSGJ). His general expertise is in the area of International Relations/International Political Economy theories and the analysis of European integration as well as resistance to neo-liberal globalisation with a particular emphasis on the possible role of trade unions and labour movements understood in a broad sense.

Jokubas Salyga is a fourth year PhD student at the School of Politics and International Relations and a Fellow at the Centre for the Study of Social and Global Justice (CSSGJ) and ZEIT-Stiftung Foundation. He holds a BA in International Relations from the Queen Mary, 
University of London, an MA in International Relations as well as an MSc in Social Research Methods from the University of Sussex. His general expertise lies in the area of historical sociology of state formation and capitalist development in the Baltic littoral. 